\title{
UV-C irradiation before or after inoculation with Colletotrichum gloeosporioides affected phytohormones and antioxidants in apple fruit (Malus domestica Borkh.)
}

\author{
O. Phonyiam, H. Tomiyama, P. Opio, T. Saito, K. Ohkawa, H. Ohara and S. Kondo \\ Graduate School of Horticulture, Chiba University, Matsudo, Chiba, Japan
}

\section{Summary}

Decay due to fungi is a major problem in the storage of apples. The effect of $3 \mathrm{~kJ} \mathrm{~m}^{-2}$ ultraviolet (UV)-C radiation applied both before and after inoculation with Colletotrichum gloeosporioides was examined. Both UV-C treatments significantly decreased the diameter of $C$. gloeosporioides lesions and maintained fruit firmness. The total phenolic concentration, total flavonoid concentration, and 2,2-diphenyl-1-picrylhydrazyl antioxidant activity were increased by the UV-C irradiation, but malondialdehyde (MDA) concentrations were significantly suppressed. UV-C irradiation before inoculation (UV-BI) increased endogenous jasmonic acid (JA) concentrations and allene oxide synthase 1 (MdAOS1), but decreased ethylene production and 1-aminocyclo-propane-1-carboxylic acid (ACC) accumulation and down-regulated their related genes [ACC synthase 1 (MdACS1), ACC synthase 3 (MdACS3), ACC oxidase 1 (MdACO1), ethylene receptor 1 (MdETR1), ethylene response sensor 1 (MdERS1), and constitutive triple response 1 (MdCTR1)] compared to UV-C after inoculation (UV-AI). In addition, UV-BI upregulated the expression of the pathogenesis-related (PR) genes MdPR1a, MdPR2, and MdPR4. These results suggest that UV-BI could inhibit the development of decay caused by $C$. gloeosporioides compared to UVAI due to the induction of endogenous JA accumulation and the up-regulation of PR genes. The crosstalk between JA and ethylene may also play a role in the defense mechanism against pathogen infection in apple fruit.

\section{Keywords}

pathogenesis-related genes, jasmonic acid, ethylene, decay, UV-C irradiation

\section{Introduction}

The development of decay after harvest caused by Colletotrichum gloeosporioides contributes to major postharvest losses in apples. Wounding or infection with a pathogen affected the signaling molecules of plant hormones such as jasmonic acid (JA) and ethylene (Khan et al., 2014). As a defensive response against pathogen attack, systemic resistance (ISR) through the JA was induced (Poveda, 2020). For example, endogenous JA and the ethylene production and ethylene-related genes; 1-aminocyclo-propane-1-carboxylic acid (ACC) ACC synthase 1 (MdACS1), ACC oxidase 1 (MdACO1), and the ethylene signal transduction genes; ethylene receptor 1 (MdETR1), ethylene response sensor 1 (MdERS1), and consti-

\section{Significance of this study}

What is already known on this subject?

- UV-C application inhibited pathogen development in several fresh fruit and vegetables.

What are the new findings?

- UV-C radiation before Colletotrichum gloeosporioides infection decreased the $C$. gloeosporioides lesion diameter through the upregulation of pathogenesisrelated genes.

What is the expected impact on horticulture?

- UV-C radiation before infection with C. gloeosporioides can inhibit decay during the storage of apples.

tutive triple response 1 (MdCTR1) were induced in apple fruit (Malus domestica) infected by Botrytis cinerea (Suktawee et al., 2019). JA is regarded as an important plant signal molecule in the defense mechanism against necrotrophic phytopathogens (Ali et al., 2018). JA application can enhance disease resistance against Fusarium oxysporum in Solanum quitoense plants (Avila et al., 2019) and can up-regulate the expression level of pathogenesis-related (PR) genes in apple leaves (Bai et al., 2013).

PR proteins are classified in various families such as antifungal proteins (PR1), $\beta$-1,3-glucanases (PR2), and chitinases (PR4), and they have properties related to plant defense against biotrophic and necrotrophic pathogens (Sels et al., 2008). For example, enhanced activity of $\beta$-1,3-glucanase and chitinase enzymes was found as part of the defense against Alternaria alternata in tomato fruit (Solanum lycopersicum) (Cota et al., 2007). PR genes have been reported in various pathosystems such as apple - Venturia inaequalis, potato - Phytophthora infestans, and tobacco - Phytophthora nicotianae (Jain and Khurana, 2018). Furthermore, the expression of PR genes has been shown to be correlated with the activation of JA and ethylene, with up-regulation of their biosynthetic-related genes (Ali et al., 2018).

Ultraviolet (UV)-C irradiation is considered to be a lowcost non-chemical treatment against postharvest diseases (Sripong et al., 2019). It has been demonstrated that UV-C radiation at a dose of $5 \mathrm{~kJ} \mathrm{~m}^{-2}$ inhibited Monilinia fruticola growth in pears (Pyrus bretschneideri Rehd.) through the induction of defense-related enzyme activity (Li et al., 2010). Sheng et al. (2018) reported that UV-C up-regulated phenolic and flavonoid biosynthetic-related genes such as phenylalanine ammonia-lyase (PAL), chalcone synthase, and flavanone 3-hydroxylase in grapes (Vitis vinifera). Moreover, the application of UV-C enhanced the signaling and biosynthesis 
of JA in Arabidopsis thaliana (Xu et al., 2016). In addition, Gangopadhyay et al. (2016) reported that UV-C priming radiation reduced the root rot disease caused by Macrophomina phaseolina in Indian Coleus (Coleus forskohlii). Therefore, UV-C irradiation may induce antioxidants, higher JA concentrations, and PR genes, and can result in the inhibition of postharvest disease. However, there are few reports on the effect of applying UV-C irradiation before pathogen infection on postharvest disease. This study investigated the effects of UV-C irradiation on C. gloeosporioides infection, PR genes, ethylene, and JA.

\section{Materials and methods}

\section{Plant material}

'Tsugaru' apple fruit were harvested at a pre-climacteric stage (See Figure 3) (5 months after full bloom) from the experimental field at Chiba University located at $36^{\circ} \mathrm{N}$ latitude, $139^{\circ} \mathrm{E}$ longitude, and $747 \mathrm{~m}$ altitude. After being harvested, the apples were thoroughly cleaned in tap water and disinfected with $0.002 \mathrm{M}$ of sodium hypochlorite $(\mathrm{NaOCl})$ for $1 \mathrm{~min}$. The fruit were then rinsed with distilled water and dried at $25^{\circ} \mathrm{C}$ overnight.

\section{Pathogen inoculation and UV-C treatment}

A C. gloeosporioides (Registration No. MAFF 239927) spore suspension at a concentration of $6 \times 10^{5}$ spores $\mathrm{mL}^{-1}$ was cultured in potato dextrose agar at room temperature for one week. The inoculation was performed according to Suktawee et al. (2019). A wound ( $5 \mathrm{~mm}$ diameter $\times 3 \mathrm{~mm}$ deep) was made on each apple fruit. The $C$. gloeosporioides mycelia agar block ( $6 \mathrm{~mm}$ diameter) was put on each wound.

Fruit were divided into three groups with 60 fruit each. The UV-C treatments were performed as follows. For UV-C before inoculation (UV-BI), UV-C irradiation was administered before the inoculation of fruit with $C$. gloeosporioides. The UV-C irradiation dose of $3 \mathrm{~kJ} \mathrm{~m}^{-2}$ was provided by six UV lamps with a peak at $253 \mathrm{~nm}$ (GL-20W, Toshiba, Japan) from a distance of $25 \mathrm{~cm}$. For UV-C after inoculation (UV-AI), UV-C irradiation was administered after the inoculation of fruit with C. gloeosporioides. An inoculated fruit that was not exposed to UV-C light was the untreated control. Following the UV-C treatment, the treated apples were kept at $25^{\circ} \mathrm{C}$ with $95 \%$ relative humidity for 16 days. The peels from 15 apples in each treatment were sampled at $0,4,12$, and 16 days after treatment (DAT), the samples were immediately frozen in liquid nitrogen and stored at $-80^{\circ} \mathrm{C}$ for analysis.

\section{Determination of lesion diameter and measurement of fruit firmness}

The lesion diameter (15 fruits per treatment) was measured using calipers every day after the inoculation. Fifteen apples per treatment were analyzed with a texture analyzer with a cylindrical probe ( $2 \mathrm{~mm}$ diameter) at a speed of $100 \mathrm{~mm} \mathrm{~min}^{-1}$ (Rheo Meter CR-100, Sun Scientific, Japan). The measurement was performed after peeling.

\section{Evaluation of total phenolic and total flavonoid concentrations and 2,2-diphenyl-1-picrylhydrazyl (DPPH) antioxidant activity}

Three grams of fresh samples ( 3 replications of 15 fruits per treatment) were extracted with $20 \mathrm{~mL}$ of $80 \%$ methanol and centrifuged at $15,000 \mathrm{~g}$ for $10 \mathrm{~min}$ at $4^{\circ} \mathrm{C}$. The total phenolic concentrations of the peels were evaluated using Folin-Ciocalteu's method according to Sheng et al. (2018).
The phenolic concentrations were monitored at $765 \mathrm{~nm}$ by spectrophotometer (U-2910, Hitachi, Japan). The total flavonoid concentration was evaluated according to Sheng et al. (2018) with modifications. The peel extract $(250 \mu \mathrm{L})$ was added to $1 \mathrm{~mL}$ of deionized water and $75 \mu \mathrm{L}$ of $5 \%$ sodium nitrite $\left(\mathrm{NaNO}_{2}\right)$. Then, $75 \mu \mathrm{L}$ of $10 \%$ aluminum chloride $\left(\mathrm{AlCl}_{3}\right)$ was added to the mixture. After $5 \mathrm{~min}, 1 \mathrm{~mL}$ of $4 \%$ sodium hydroxide $(\mathrm{NaOH})$ was added. This reaction mixture was measured at $510 \mathrm{~nm}$. The DPPH antioxidant activity was determined according to Phonyiam et al. (2016) with slight modifications. A $500 \mu \mathrm{L}$ volume of the sample extract was mixed with $1.5 \mathrm{~mL}$ of $0.1 \mathrm{mM}$ DPPH-methanolic solution. The decrease of absorbance was monitored at $517 \mathrm{~nm}$ after incubation in the dark for $30 \mathrm{~min}$.

\section{Measurement of malondialdehyde (MDA) concentration}

Lipid peroxidation was examined based on the production of MDA according to Phonyiam et al. (2016) with modifications. One gram of fresh sample (3 replications of 15 fruits per treatment) was homogenized with $7 \mathrm{~mL}$ of $10 \%$ trichloroacetic acid (TCA). The homogenate was centrifuged at $15,000 \mathrm{~g}$ for $10 \mathrm{~min}$ at $4^{\circ} \mathrm{C}$. Thereafter, the supernatant of $500 \mu \mathrm{L}$ was mixed with $1.5 \mathrm{~mL}$ of $0.5 \%$ thiobarbituric acid in $10 \%$ TCA and thereafter incubated in $85^{\circ} \mathrm{C}$ for $30 \mathrm{~min}$. The cooled mixture was measured at $532 \mathrm{~nm}$ using a spectrophotometer. The non-specific turbidity of MDA was determined at the absorbance of $600 \mathrm{~nm}$.

\section{Measurement of JA concentration}

The endogenous JA concentration was determined according to Segarra et al. (2006). Fresh samples, that were 0.5 grams (3 replications of 15 fruits per treatment) were homogenized with $5 \mathrm{~mL}$ of $\mathrm{MeOH}-\mathrm{H}_{2} \mathrm{O}-\mathrm{CH}_{3} \mathrm{COOH}$ (90:9:1, $\mathrm{v} / \mathrm{v} / \mathrm{v}$ ) and $100 \mu \mathrm{L}$ of $10^{-4} \mathrm{M}$ of ibuprofen, which was used as the internal standard. The homogenate was separated after centrifugation at $15,000 \mathrm{~g}$ for $10 \mathrm{~min}$ at $4^{\circ} \mathrm{C}$. The supernatant was dried at $37^{\circ} \mathrm{C}$ and filtered with $1 \mathrm{~mL}$ of methanol using absolute high-performance liquid chromatography with an Omnipore 0.45- $\mu \mathrm{m}$ filter (Millipore, Bedford, U.S.A.). Analysis and quantification of extract containing JA was carried out using a liquid chromatograph mass spectrometer (LCMS-2010EV; Shimadzu, Kyoto, Japan). A $5 \mu$ L injected volume was monitored through an RP-18 octadecylsilyl column ( $5 \mu \mathrm{m}, 2$ mm I.D. × 150 mm; Kanto Chemical, Tokyo, Japan). The JA concentration was calculated from the ratio of the peak area for $m / z$ 206/161 (ibuprofen).

\section{Determination of ethylene and ACC concentration}

Ethylene production was examined according to Suktawee et al. (2019). Apple fruits ( 3 replications of 15 fruits per treatment) were sealed in a plastic jar of $1.7 \mathrm{~L}$ and incubated at $25^{\circ} \mathrm{C}$ for one hour. A $1 \mathrm{~mL}$ gas sample was analyzed by gas chromatography (GC-2014; Shimadzu, Kyoto, Japan). ACC concentrations were evaluated based on Suktawee et al. (2019) with slight modifications. One gram of peel (3 replications of 15 fruits per treatment) was extracted with $10 \mathrm{~mL}$ of $0.1 \mathrm{M} \mathrm{HCl}$. The reaction mixture, which contained $2 \mathrm{~mL}$ of crude extract, $0.2 \mathrm{~mL}$ of $0.1 \mathrm{M} \mathrm{HgCl}_{2}$, and $0.2 \mathrm{~mL}$ of $5 \% \mathrm{NaOCl}$, was rapidly mixed and monitored by gas chromatography.

\section{Measurement of total RNA extraction and quantitative reverse-transcription polymerase chain reaction (qRT- PCR) analysis}

The total RNA was extracted from the apple peel. A $500 \mathrm{mg}$ sample of peel ( 3 replications of 15 fruits per treat- 
TABLE 1. Primer sequences used for quantitative real-time reverse transcription polymerase chain reaction (qRT-PCR) analyses.

\begin{tabular}{|c|c|c|}
\hline Gene name & Primer sequences $\left(5^{\prime}-3^{\prime}\right)$ & References/Accession No. \\
\hline MdACS1 & $\begin{array}{l}\text { (F) TCACCTCAATATATCTCCTGGA } \\
\text { (R) CCTCAGGGACGTTGTAATAC }\end{array}$ & U89156 \\
\hline MdAC01 & $\begin{array}{l}\text { (F) GTTCTACAACCCAGGCAACG } \\
\text { (R) TCTCAGAGCTCAGGCAGTTG }\end{array}$ & NM001294118 \\
\hline MdETR1 & $\begin{array}{l}\text { (F) GGGGCGACTCATCTTATCAA } \\
\text { (R) CACCACCGCAGTTAAAACCT }\end{array}$ & AF032448 \\
\hline MdERS1 & $\begin{array}{l}\text { (F) CAGATGAGCTGCTGGTGAAA } \\
\text { (R) TATGAGCTCCAAGGGAATGG }\end{array}$ & AY083169 \\
\hline MdCTR1 & $\begin{array}{l}\text { (F) ACTTCTTGGATCCAGTGCCG } \\
\text { (R) GACAGACAGCCATTCACCCA }\end{array}$ & DQ847149 \\
\hline MdAOS1 & $\begin{array}{l}\text { (F) GGGAGAAGCTGTTGAAGCAC } \\
\text { (R) TCCAGCACACTGTTTGTTCC }\end{array}$ & XM008366758 \\
\hline MdPR1a & $\begin{array}{l}\text { (F) GCTCAGCCGTAATACAATCCTCTC } \\
\text { (R) TACCCCCACTACTGCACCTCACT }\end{array}$ & DQ318212 \\
\hline MdPR2 & $\begin{array}{l}\text { (F) CTTCACAGTCACCATCTTCAACA } \\
\text { (R) GGTGCACCAGCTTTTTCAA }\end{array}$ & AY548364 \\
\hline MdPR4 & $\begin{array}{l}\text { (F) ATACCACCTCTACAATCCACA } \\
\text { (R) GTCCAAGTCCAATCCTCC }\end{array}$ & XM008372483 \\
\hline MdSAND & $\begin{array}{l}\text { (F) CCCAGGACTTTGAGCTTTATGC } \\
\text { (R) TATCACCATGAAAAGGGGCTTG }\end{array}$ & Mimida et al. (2015) \\
\hline MdUBQ & $\begin{array}{l}\text { (F) CTCCGTGGTGGTTTTTAAGT } \\
\text { (R) GGAGGCAGAAACAGTACCAT }\end{array}$ & U74358 \\
\hline MdHISH3 & $\begin{array}{l}\text { (F) GTCAAGAAGCCCCACAGATAC } \\
\text { (R) CTGGAAACGCAGATCAGTCTTG }\end{array}$ & AY347801 \\
\hline
\end{tabular}
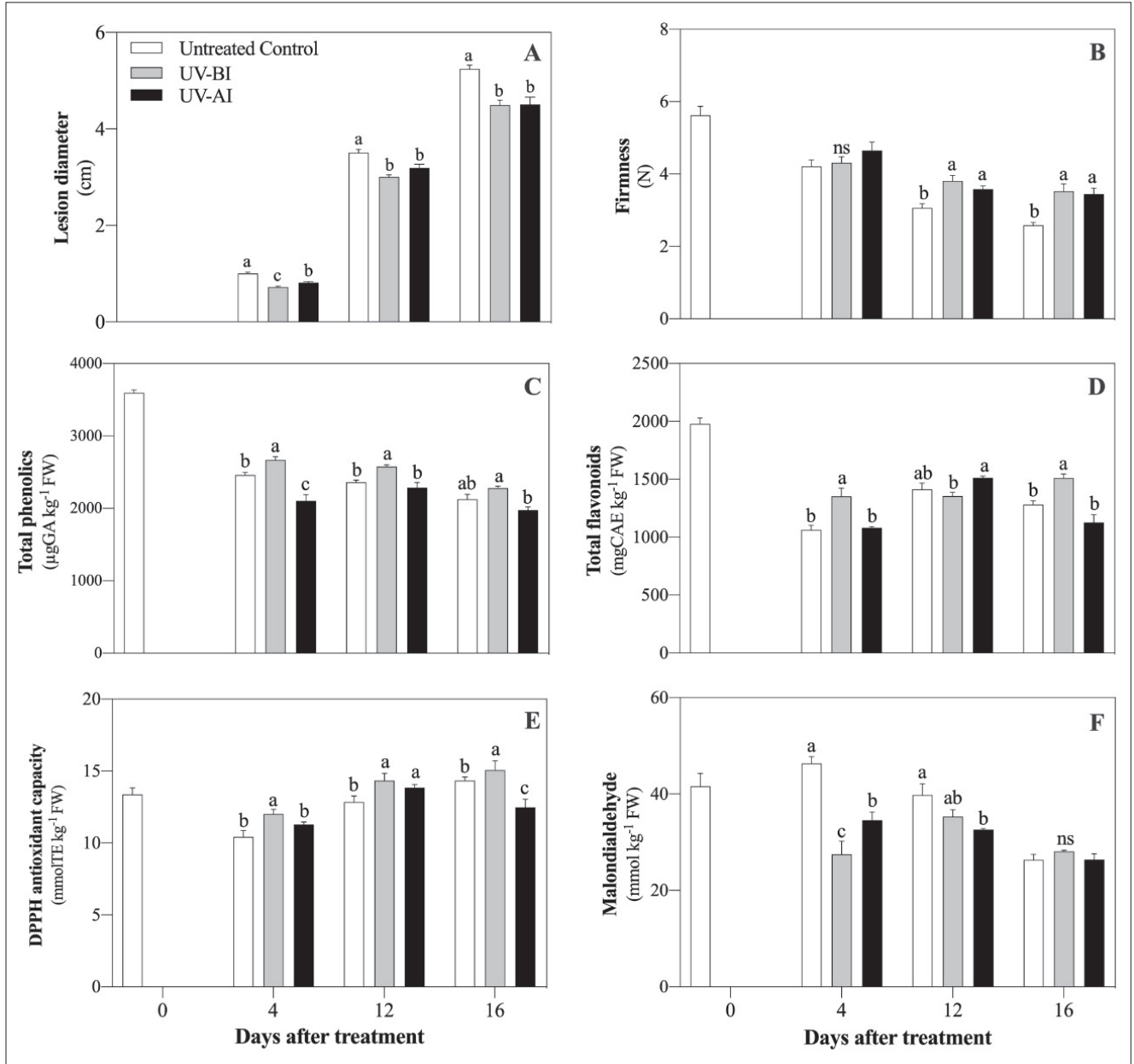

FigurE 1. Effect of UV-C irradiation on lesion diameters (A), fruit firmness (B), total phenols (C), total flavonoids (D), DPPH antioxidant capacity (E), and malondialdehyde (F) in the untreated control, UV-BI, and UVAI treatments. The different letters indicate significant differences at $P \leq 0.05$ as determined by an LSD test each day with the mean \pm SE of three replications of 15 fruits per treatment; ns: no significant difference. 
ment) was extracted by the modified cetyl trimethylammonium bromide method (Henderson and Hammond, 2013). The purified RNA quality and integrity were determined using a UV spectrophotometer (SmartSpec Plus, Bio Rad, U.S.A.) in the ratio of A260/A280 and by agarose gel electrophoresis, respectively. The first strand CDNA was synthesized by the reversion of RNA using Revertra Ace qPCR RT Master Mix (Toyobo, Osaka, Japan), and a final concentration of $500 \mathrm{ng}$ $50 \mu \mathrm{L}^{-1}$ was used as the reaction mix for qRT-PCR analysis. The gene specific primers were used for qRT-PCR examination (Table 1). The analysis was performed using qRT-PCR (StepOnePlus ${ }^{\mathrm{TM}}$; Applied Biosystems, Foster City, CA, U.S.A.) with Kapa Sybr Fast qPCR Master Mix ABI Prism (Kapa Biosystems, Wilmington, MA, U.S.A.). The expression of each gene was examined using the quantitation comparative cycle threshold $\left(2^{-\Delta \Delta \mathrm{Ct}}\right)$ to normalize to the Ct values of MdSAND, $M d U B Q$, and MdHISH3.

\section{Statistical analysis}

All results are shown as the mean \pm standard error (SE). The statistical analysis of variance was performed using the least significant difference (LSD) test at $P \leq 0.05$ (SPSS 16; IBM Corp., Armonk, NY, U.S.A.).

\section{Results}

\section{Lesion diameter and fruit firmness}

UV-C irradiation significantly reduced the lesion diameter compared to the untreated control throughout the storage period with a profound effect at 16 DAT (UV-BI was $4.51 \pm 0.15 \mathrm{~cm}$, UV-AI was $4.49 \pm 0.11 \mathrm{~cm}$, and the untreated

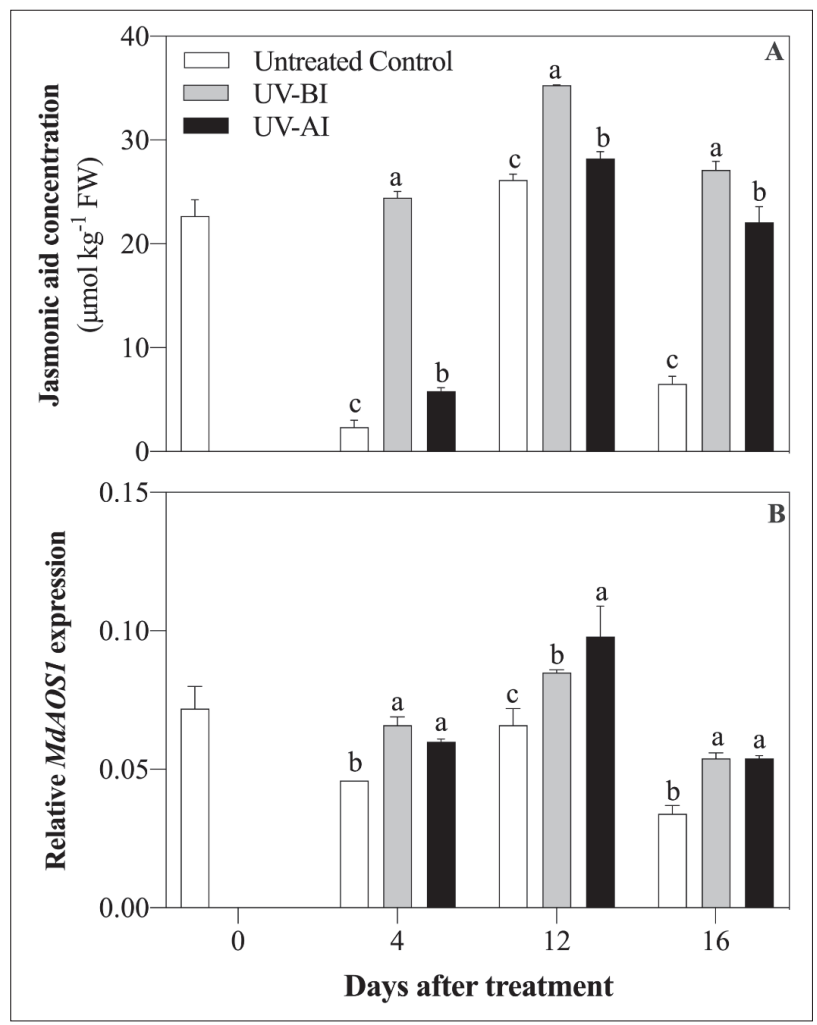

FIGURE 2. Effect of UV-C irradiation on jasmonic acid (A) and the expression of MdAOS1 (B) in the untreated control, UV-BI, and UV-AI treatments. The different letters indicate significant differences at $P \leq 0.05$ as determined by an LSD test each day with the mean \pm SE of three replications of 15 fruits per treatment; ns: no significant difference. control was $5.04 \pm 0.08 \mathrm{~cm}$ ) (Figure $1 \mathrm{~A}$ ). UV-C irradiation significantly delayed the decrease of firmness in apple fruit at 12 and 16 DAT compared with the untreated control (Figure 1B). The soluble solid content and titratable acidity did not show any significant difference among the treatments (data not presented).

\section{Total phenolic and total flavonoid concentrations, DPPH antioxidant activity, and MDA concentration}

The total phenolic concentration was generally increased by UV-BI throughout the storage period compared with the other treatments (Figure 1C). UV-BI significantly enhanced the total flavonoid concentration at 4 and 16 DAT compared with the other groups (Figure 1D). In the UV-AI, the total flavonoid concentration was most increased at 12 DAT and was decreased at 16 DAT. UV-BI irradiation significantly increased DPPH activity compared to the untreated control (Figure 1E). The DPPH activity in the UV-AI group at 12 DAT was higher than that in the untreated control, but it decreased at 16 DAT. The MDA concentration was significantly decreased by both UV-BI and UV-AI irradiation at 4 DAT. There were no significant differences at 16 DAT among the treatments.

\section{JA concentration and expression of allene oxide synthase 1 (MdAOS1)}

The UV-BI significantly increased the JA concentration at 4,12 , and 16 DAT compared with the UV-AI and untreated control groups (Figure 2A). UV-AI also showed higher JA concentrations than the untreated control. The expression of MdAOS1 in both the UV-BI and UV-AI groups was significantly up-regulated compared to the untreated control at 4,12, and 16 DAT (Figure 2B).

\section{Ethylene production, ACC concentration, and ethylene- related genes}

In general, ethylene production in the untreated control was higher than that with UV-C irradiation during storage (Figure 3A). Ethylene production in the untreated control was highest at 16 DAT. The ACC concentration in the untreated control was highest at 12 DAT (Figure 3B). The UV-BI and UV-AI generally down-regulated the expression levels of MdACS1 compared with that of the untreated control (Figure 3C). The MdACO1 expression levels in UV-BI and UV-AI decreased significantly at 4 and 16 DAT (Figure 3D). The expression levels of MdETR1, MdERS1, and MdCTR1 under both the UV-BI and UV-AI treatments were significantly lower than those in the untreated control (Figure 3E-G).

\section{PR genes}

The expression level of MdPR1a was significantly increased by UV-BI and UV-AI irradiation compared to the untreated control at 4 and 12 DAT (Figure 4A). In general, $M d P R 2$ in each treatment gradually decreased during storage (Figure 4B). The expression of MdPR2 was up-regulated by UV-BI at 4 and 12 DAT compared to that of the untreated control group. The expression of MdPR4 was significantly upregulated by the UV-AI treatment (Figure 4C).

\section{Discussion}

UV-C irradiation limited the proliferation of foodborne pathogens including Escherichia coli, Listeria innocua or Salmonella enterica in apples (Graça et al., 2013) and inhibited decay caused by B. cinerea in strawberries (Fragaria ananassa) (Jin et al., 2017). In our study, both UV-BI and UV-AI at a dose of $3 \mathrm{~kJ} \mathrm{~m}^{-2}$ decreased the lesion diameter 
of C. gloeosporioides in apple fruit. This is comparable to the findings of earlier studies by Charles et al. (2009) and Sripong et al. (2019), who demonstrated that UV-C could induce disease resistance through increasing plant-defense-related enzymes like PAL, peroxidase, and chitinase, which are involved in activating PR proteins such as PR2 in the man- gosteen (Garcinia mangostana L.) and tomato. On the other hand, Severo et al. (2015) indicated that UV-C may delay fruit softening due to the decrease in the expression of firmnessassociated genes such as pectate lyase a (PLa), PLb, and PLc in the strawberry. These results are consistent with our finding that both UV-BI and UV-AI significantly delayed soften-

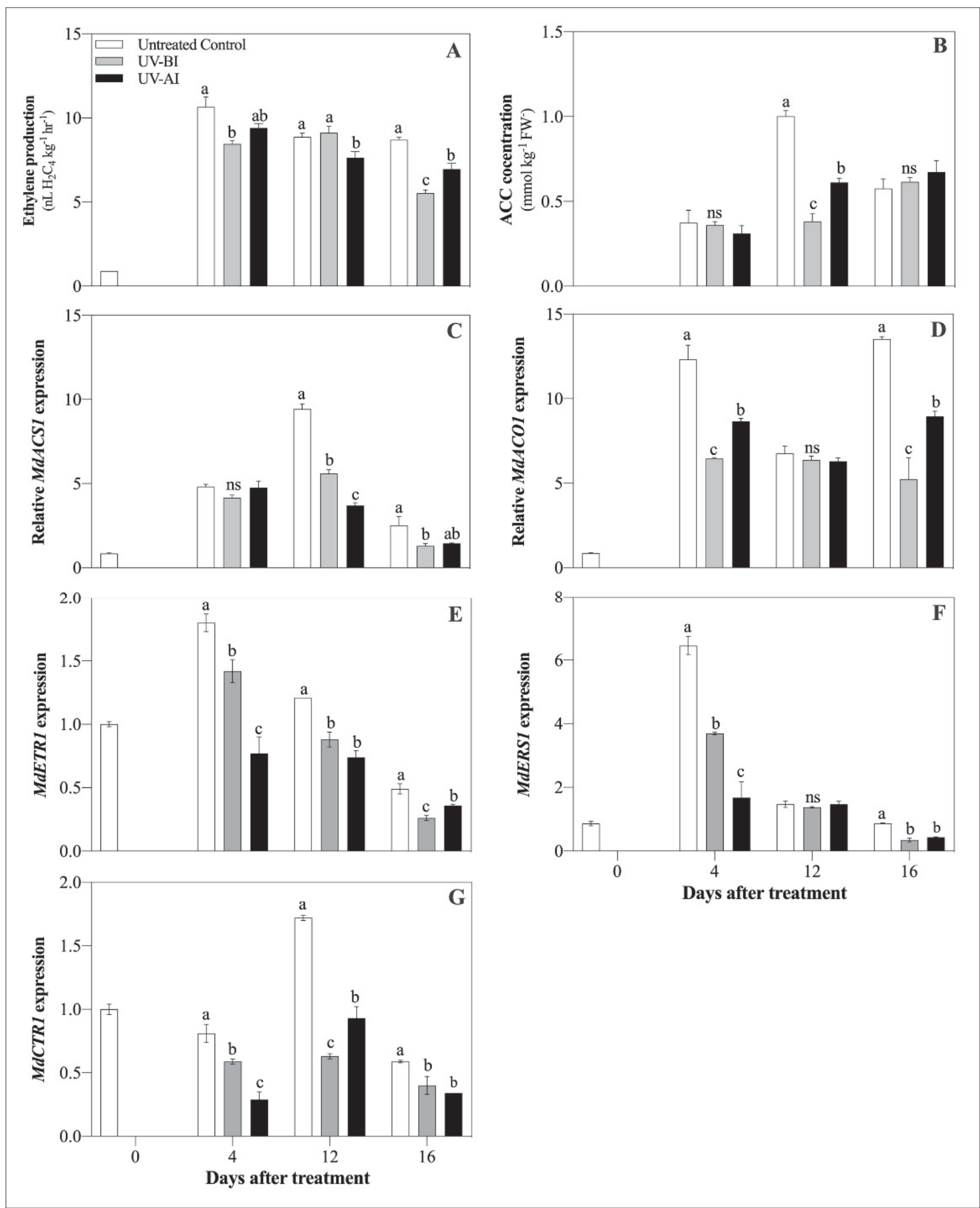

FigURE 3. Effect of UV-C irradiation on ethylene production (A), ACC concentration (B), and the expressions of MdACS1 (C), MdACO1 (D), MdETR1 (E), MdERS1 (F), and MdCTR1 (G) in the untreated control, UV-BI, and UV-AI treatments. The different letters indicate significant differences at $P \leq 0.05$ as determined by an LSD test each day with the mean \pm SE of three replications of 15 fruits per treatment; ns: no significant difference. 
ing in infected apple fruit. Moreover, Kesari et al. (2010) reported that a decrease in fruit firmness could promote the activity of PR1a.

UV-C radiation stimulated the total phenolic and flavonoid concentrations in wheat (Triticum aestivum) and lettuce (Lactuca sativa) (Ouhibi et al., 2014; Badridze et al., 2015). Our study showed that UV-BI increased the total phenolic and flavonoid concentrations compared to UV-AI and the untreated control in apples infected with C. gloeosporioides. These results suggest that the increases in bioactive substances such as phenols and flavonoids were immediately induced after irradiation with UV-C. UV-C irradiation may enhance the synthesis of secondary metabolites associated with the inhibition of pathogen infection. Furthermore, our study also revealed that UV-BI increased DPPH antioxidant activity. Jin et al. (2017) confirmed that UV-C treatment promoted antioxidant enzyme activities and inhibited gray mold
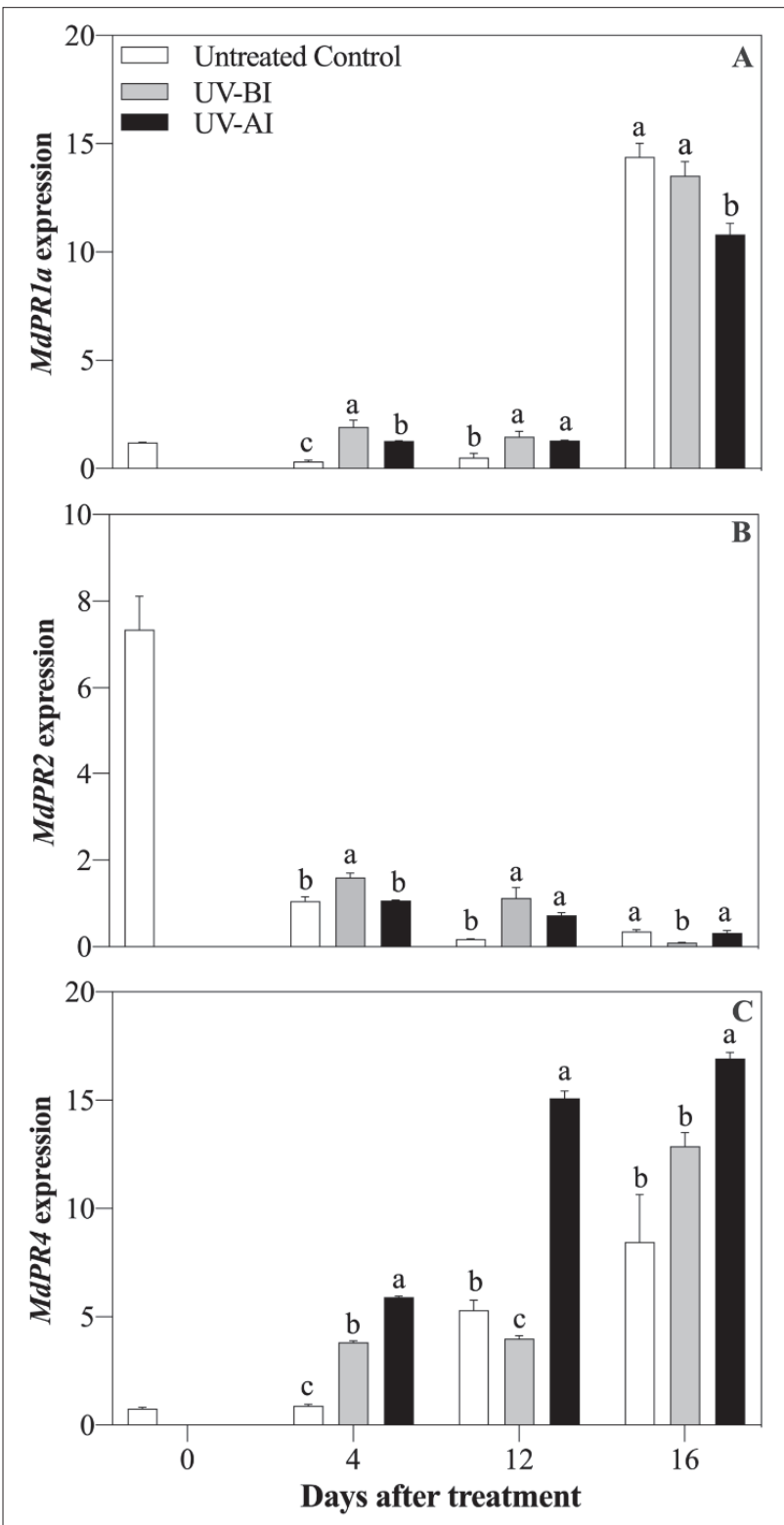

FIGURE 4. Effect of UV-C irradiation on the expressions of MdPR1a (A), MdPR2 (B), and MdPR4 (C) in the untreated control, UV-BI, and UV-AI treatments. The different letters indicate significant differences at $P \leq 0.05$ as determined by an LSD test each day with the mean \pm SE of three replications of 15 fruits per treatment; ns: no significant difference. development in strawberry fruit. Li et al. (2019) and Xu et al. (2019) showed that phenolic, flavonoid, and overall antioxidant activities were increased via the stimulation of their key enzymes, namely PAL, cinnamate-4-hydroxylase, and 4-coumarate coenzyme A ligase, after exposure to UV-C radiation. Our results suggest that the UV-BI treatment induced disease resistance prior to infection with C. gloeosporioides through the enhanced accumulation of phenols and flavonoids as well as through increased DPPH antioxidant activity.

MDA is part of the secondary end-product of lipid peroxidation which results in membrane structure damage (He et al., 2019). The previous research showed that UV-C irradiation suppressed the production of MDA and lipoxygenase activity, which caused lipid membrane degradation and resulted in control of crown rot disease in bananas (Musa AAA) (Pongprasert et al., 2011). In our study, UV-C treatment decreased MDA concentrations. Therefore, lower MDA production may preserve the integrity of the cell membrane structure and subsequently promote resistance against infection with C. gloeosporioides.

It has been shown that JA promoted plant resistance against pathogens by inducing antimicrobial compounds and activating plant signaling molecules (Shigenaga and Argueso, 2016). A previous study demonstrated that UV-C treatment induced JA accumulation in strawberry fruit during storage (Xu et al., 2019). Moreover, Xu et al. (2017) reported that JA affected the antioxidant activity in plants. These results agree with our results, which showed that apple fruit exposed to UV-BI significantly promoted endogenous JA and increased total phenolic and flavonoid concentrations as well as antioxidant activity and PR gene expression. Our results suggest that the increase of JA accumulation may have increased

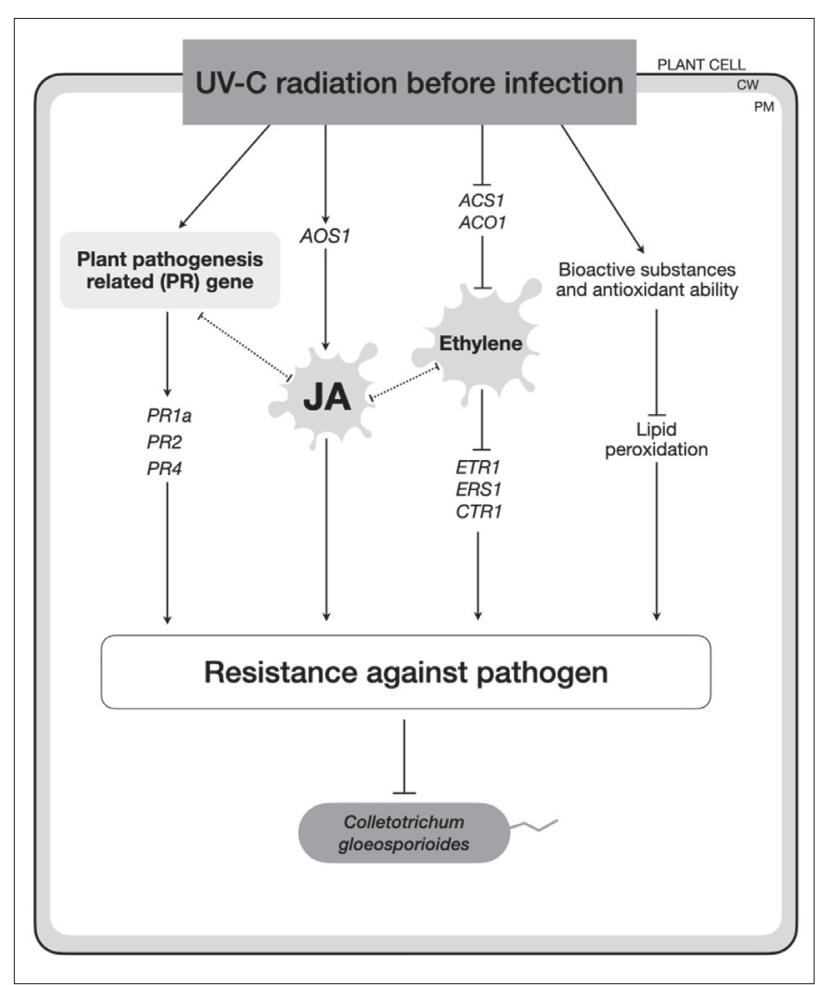

FIGURE 5. Overview of the potential effect of UV-C irradiation on phytohormones and antioxidant activity in apple fruit. The solid lines indicate UV-C-mediated up-regulation or stimulation (arrow) and inhibition (blunt-end line). Dashed lines indicate some interaction or process involved in hormone crosstalk. $\mathrm{CW}=$ cell wall, $\mathrm{PM}=$ plasma membrane . 
the antioxidant activity involved in the up-regulation of PR genes. The allene oxide synthase (AOS) is a dominant key gene for the biosynthesis of JA (Garrido-Bigotes et al., 2018), and our study found that the expression of MdAOS1 was stimulated by UV-C irradiation. JA concentrations may have increased through the increase in MdAOS1 expression.

Ethylene plays a role in fruit ripening and in plant defense against pathogens. For example, it has been reported that UV-C radiation suppressed ethylene biosynthesis in the tomato, banana, and mango (Mangifera indica) (Bu et al., 2013; Pristijono et al., 2018). Our result also showed that UV-BI decreased ethylene production as well as the ACC concentrations. Moreover, UV-BI also down-regulated the transcript levels of ethylene biosynthesis genes (MdACS1 and MdACO1) and signal transduction genes (MdETR1, MdERS1 and MdCTR1). These results may be associated with the JA accumulation. Sun et al. (2016) reported that both ethylene and JA signaling play a role in regulating necrotrophic pathogens. For example, the interaction between ethylene and JA revealed that JASMONATE ZIM DOMAIN PROTEIN down-regulated the transcripts of ETHYLENE INSENSITIVE 3 (EIN3) and EIN3-like 1, resulting in the stimulation of defense proteins such as PLANT DEFENSIN 1.2 (Yang et al., 2019). Therefore, this suggests that a reduction of ethylene biosynthesis is required during JA signaling for UV-BI to enhance the plant defense against $C$. gloeosporioides.

The accumulation of PR proteins is frequently used as a defensive marker against phytopathogens such as viruses, bacteria, and fungi (Sels et al., 2008). The induction of the $P R 1$ and PR2 genes was considered to activate phytohormones such as JA and ethylene (Ali et al., 2017). For example, enhanced expression of MpNPR1 promoted pathogen defense against apple diseases caused by Erwinia amylovora (Malnoy et al., 2008). Furthermore, Sarowar et al. (2005) also reported that high resistance to oomycete and bacterial pathogens in tobacco (Nicotiana tabacum) was stimulated by the overexpression of CABPR1. Besides, PR2 family genes played a role in plant defense through the deconstruction of the cell walls of pathogenic fungi (Balasubramanian et al., 2012). Our results also showed that the expressions of MdPR1a and MdPR2 were up-regulated by UV-C irradiation. Jin et al. (2017) reported that UV-C treatment prior to $B$. cinerea inoculation induced defense-related genes such as cinnamoyl CoA reductase-1 allele, chitinase, polyphenol oxidase, and PAL6 in strawberry fruit. PR4 is categorized as a chitinase enzyme, which particularly functions in the plant defense response through hydrolyzing chitin-containing pathogen cell walls (Hamid et al., 2013). Our results showed that the expression level of MdPR4 was up-regulated by UV-C application. These results agree with those of Bai et al. (2013), who demonstrated that an up-regulated expression of MdPR4 may be related to ribonuclease activity that is associated with antifungal mechanism.

\section{Conclusion}

The UV-BI was more efficient in suppressing C. gloeosporioides than UV-AI through increasing the JA concentration and the expression of MdAOS1, decreasing ethylene production, and down-regulating MdACS1, MdACO1, MdETR1, $M d E R S 1$, and MdCTR1 expressions, as well as up-regulating $P R$ genes. In addition, the total phenolic and flavonoid concentrations and DPPH antioxidant activity were increased by UV-BI irradiation. UV-BI may induce the apple defense mechanism against $C$. gloeosporioides through the synergistic interaction of the $P R$ gene and crosstalk between JA and ethylene.

\section{References}

Ahn, S.Y., Kim, S.A., and Yun, H.K. (2014). Differential Expression of $\beta$-1,3-glucanase transcripts induced by pathogens in the leaves of Vitis flexuosa. Plant Breed. Biotechnol. 2(2), 176-183. https://doi. org/10.9787/PBB.2014.2.2.176.

Ali, S., Ganai, B.A., Kamili, A.N., Bhat, A.A., Mir, Z.A., Bhat, J.A., Tyagi, A., Islam, S.T., Mushtaq, M., Yadav, P., Rawat, S., and Grover, A. (2018). Pathogenesis-related proteins and peptides as promising tools for engineering plants with multiple stress tolerance. Microbiol. Res. 212-213, 29-37. https://doi.org/10.1016/j.micres.2018.04.008.

Ali, S., Zahoor, A.M., Tyagi, A., Bhat, J.A., Chandrashekar, N., Papolu, P.K., Rawat, S., and Grover, A. (2017). Identification and comparative analysis of Brassica juncea pathogenesis-related genes in response to hormonal, biotic and abiotic stresses. Acta Physiol. Plant. 39(12), 268. https://doi.org/10.1007/s11738-017-2565-8.

Avila, A.C., Ochoa, J., Proano, K., and Martinez, M.C. (2019). Jasmonic acid and nitric oxide protects naranjilla (Solanum quitoense) against infection by Fusarium oxysporum F. sp. quitoense by eliciting plant defense responses. Physiol. Mol. Plant. P. 106, 129-136. https://doi. org/10.1016/j.pmpp.2019.01.002.

Badridze, G., Kacharava, N., Chkhubianishvili, E., Rapava, L., Kikvidze, M., Chanishvili, S., and Chigladze, L. (2015). Influence of ultraviolet irradiation and acid precipitations on the content of antioxidants in wheat leaves. Appl. Ecol. Env. Res. 13(4), 993-1013.

Bai, S., Dong, C., Li, B., and Dai, H. (2013). A PR-4 gene identified from Malus domestica is involved in the defense responses against Botryosphaeria dothidea. Plant Physiol. Biochem. 62, 23-32. https:// doi.org/10.1016/j.plaphy.2012.10.016.

Balasubramanian, V., Vashisht, D., Cletus, J., and Sakthivel, N. (2012). Plant $\beta$-1,3-glucanases: Their biological functions and transgenic expression against phytopathogenic fungi. Biotechnol. Lett. 34(11), 1983-1990. https://doi.org/10.1007/s10529-012-1012-6.

Bu, J., Yu, Y., Aisikaer, G., and Ying, T. (2013). Postharvest UV-C irradiation inhibits the production of ethylene and the activity of cell wall-degrading enzymes during softening of tomato (Lycopersicon esculentum L.) fruit. Postharvest Biol. Technol. 86, 337-345. https:// doi.org/10.1016/j.postharvbio.2013.07.026.

Cota, I.E., Troncoso-Rojas, R., Sotelo-Mundo, R., Sánchez-Estrada, A., and Tiznado-Hernández, M.E. (2007). Chitinase and $\beta$-1,3-glucanase enzymatic activities in response to infection by Alternaria alternata evaluated in two stages of development in different tomato fruit varieties. Sci. Hortic. 112(1), 42-50. https://doi.org/10.1016/j. scienta.2006.12.005.

Garrido-Bigotes, A., Figueroa, N.E., Figueroa, P.M., and Figueroa, C.R. (2018). Jasmonate signalling pathway in strawberry: Genomewide identification, molecular characterization and expression of JAZs and MYCs during fruit development and ripening. PloS ONE 13, e0197118. https://doi.org/10.1371/journal.pone.0197118.

Graça, A., Salazar, M., Quintas, C., and Nunes, C. (2013). Low dose UV-C illumination as an eco-innovative disinfection system on minimally processed apples. Postharvest Biol. Technol. 85, 1-7. https://doi. org/10.1016/j.postharvbio.2013.04.013.

Guerrero, R.F., Cantos-Villar, E., Fernández-Marín, M.I., Puertas, B., and Serrano-Albarrán, M.J. (2015). Optimising UV-C preharvest light for stilbene synthesis stimulation in table grape: Applications. Innov. Food Sci. Emerg. Technol. 29, 222-229. https://doi.org/10.1016/j. ifset.2015.02.010.

He, Y., Li, Z., Tan, F., Liu, H., Zhu, M., Yang, H., Bi, G., Wan, H., Wang, J., $\mathrm{Xu}$, R., Wen, W., Zeng, Y., Xu, J., Guo, W., Xue, S., Cheng, Y., and Deng, X. (2019). Fatty acid metabolic flux and lipid peroxidation homeostasis maintain the biomembrane stability to improve citrus fruit storage performance. Food Chem. 292, 314-324. https://doi.org/10.1016/j. foodchem.2019.04.009. 
Henderson, D., and Hammond, J. (2013). CKC: isolation of nucleic acids from a diversity of plants using CTAB and silica columns. Mol. Biotechnol. 53, 109-117. https://doi.org/10.1007/s12033-0129494-y.

Hossain, M.A., and Rahman, S.M.M. (2011). Total phenolics, flavonoids and antioxidant activity of tropical fruit pineapple. Food Res. Int. 44, 672-676. https://doi.org/10.1016/j.foodres.2010.11.036.

Jain D., and Khurana J.P. (2018). Role of pathogenesis-related (PR) proteins in plant defense mechanism. In Molecular Aspects of PlantPathogen Interaction, A. Singh, and I. Singh, eds. (Singapore: Springer), p. 265-281. https://doi.org/10.1007/978-981-10-7371-7_12.

Jin, P., Wang, H., Zhang, Y., Huang, Y., Wang, L., and Zheng, Y. (2017). UV-C enhances resistance against gray mold decay caused by Botrytis cinerea in strawberry fruit. Sci. Hortic. 225, 106-111. https://doi. org/10.1016/j.scienta.2017.06.062.

Khan, M., Rozhon, W., and Poppenberger, B. (2014). The role of hormones in the aging of plants - A mini-review. Gerontology 60, 49-55. https://doi.org/10.1159/000354334.

Li, J., Zhang, Q., Cui, Y., Yan, J., Cao, J., Zhao, Y., and Jiang, W. (2010). Use of UV-C treatment to inhibit the microbial growth and maintain the quality of yali pear. J. Food Sci. 75, 503-507. https://doi. org/10.1111/j.1750-3841.2010.01776.x.

Li, M., Li, X., Han, C., Ji, N., Jin, P., and Zheng, Y. (2019). UV-C treatment maintains quality and enhances antioxidant capacity of fresh-cut strawberries. Postharvest Biol. Technol. 156, 110945. https://doi. org/10.1016/j.postharvbio.2019.110945.

Liu, H., Carvalhais, L.C., Kazan, K., and Schenk, P.M. (2016). Development of marker genes for jasmonic acid signaling in shoots and roots of wheat. Plant Signal. Behav. 11(5), e1176654. https:// doi.org/10.1080/15592324.2016.1176654.

Malnoy, M., Jin, Q.L., Borejsza, W.E., He, S.Y., and Aldwinckle, H.S. (2008). Overexpression of the apple MpNPR1 gene confers increased disease resistance in Malus domestica. Mol. Plant Microbe Interact. 20(12), 1568-1580. https://doi.org/10.1094/MPMI-20-12-1568.

Mimida, N., Saito, T., and Moriguchi, T. (2015). Expression of DORMANCY-ASSOCIATED MADS-BOX (DAM)-like genes in apple. Biol. Plant. 59, 237-244. https://doi.org/10.1007/s10535-015-0503-4.

Mohamed, S.N.P., Ding, P., Kadir, J., and Ghazali, H.M. (2017). Potential of UVC germicidal irradiation in suppressing crown rot disease, retaining postharvest quality and antioxidant capacity of Musa AAA 'Berangan' during fruit ripening. Food Sci. Nutr. 5(5), 967-980. https://doi.org/10.1002/fsn3.482.

Ouhibi, C., Attia, H., Rebah, F., Msilini, N., Chebbi, M., Aarrouf, J., Urban, L., and Lachaal, M. (2014). Salt stress mitigation by seed priming with UV-C in lettuce plants: Growth, antioxidant activity and phenolic compounds. Plant Physiol. Biochem. 83, 126-133. https:// doi.org/10.1016/j.plaphy.2014.07.019.

Park, M.H., and Kim, J.G. (2015). Low-dose UV-C irradiation reduces the microbial population and preserves antioxidant levels in peeled garlic (Allium sativum L.) during storage. Postharvest Biol. Technol. 100, 109-112. https://doi.org/10.1016/j.postharvbio.2014.09.013.

Phonyiam, O., Kongsuwan, A., and Setha, S. (2016). Effect of shortterm anoxic treatment on internal browning and antioxidant ability in pineapple cv. Phulae. Int. Food Res. J. 23(2), 521-527.

Pongprasert, N., Sekozawa, Y., Sugaya, S., and Gemma, H. (2011). A novel postharvest UV-C treatment to reduce chilling injury (membrane damage, browning and chlorophyll degradation) in banana peel. Sci. Hortic. 130, 73-77. https://doi.org/10.1016/j. scienta.2011.06.006

Poveda, J. (2020). Use of plant-defense hormones against pathogendiseases of postharvest fresh produce. Physiol. Mol. Plant Pathol. 111, 101521. https://doi.org/10.1016/j.pmpp.2020.101521.
Pristijono, P., Bowyer, M.C., Scarlett, C.J., Vuong, Q.V., Stathopoulos, C.E., and Golding, J.B. (2019). The application of UV-C irradiation followed by storage in continuous low level ethylene atmosphere to delay the ripening of mature green tomatoes. Acta Hortic. 1256, 335-342. https://doi.org/10.17660/ActaHortic.2019.1256.47.

Pristijono, P., Golding, J.B., and Bowyer, M.C. (2018). Postharvest UV-C treatment, followed by storage in a continuous low-level ethylene atmosphere, maintains the quality of 'Kensington Pride' mango fruit stored at $20^{\circ} \mathrm{C}$. Horticulturae 5(1). https://doi.org/10.3390/ horticulturae 5010001.

Sarowar, S., Kim, Y.J., and Kim, E.N. (2005). Overexpression of a pepper basic pathogenesis-related protein 1 gene in tobacco plants enhances resistance to heavy metal and pathogen stresses. Plant Cell Rep. 24, 216-224. https://doi.org/10.1007/s00299-005-0928-x.

Segarra, G., Jáuregui, O., Casanova, E., and Trillas, I. (2006). Simultaneous quantitative LC-ESI-MS/MS analyses of salicylic acid and jasmonic acid in crude extracts of Cucumis sativus under biotic stress. Phytochemistry 67, 395-401. https://doi.org/10.1016/j. phytochem.2005.11.017.

Sels, J., Mathys, J., De Coninck, B.M.A., Cammue, B.P.A., and De Bolle, M.F.C. (2008). Plant pathogenesis-related (PR) proteins: A focus on PR peptides. Plant Physiol. Biochem. 46(11), 941-950. https://doi. org/10.1016/j.plaphy.2008.06.011.

Severo, J., Oliveira, I.R., Tiecher, A., Chaves, F.C., and Rombaldi, C.V. (2015). Postharvest UV-C treatment increases bioactive, ester volatile compounds and a putative allergenic protein in strawberry. LWT Food Sci. Technol. 64, 685-692. https://doi.org/10.1016/j. lwt.2015.06.041.

Sheng, K., Zheng, H., Shui, S., Yan, L., Liu, C., and Zheng, L. (2018). Comparison of postharvest UV-B and UV-C treatments on table grape: Changes in phenolic compounds and their transcription of biosynthetic genes during storage. Postharvest Biol. Technol. 138, 74-81. https://doi.org/10.1016/j.postharvbio.2018.01.002.

Shigenaga, A.M., and Argueso, C.T. (2016). No hormone to rule them all: Interactions of plant hormones during the responses of plants to pathogens. Semin. Cell Dev. Biol. 56, 174-189. https://doi. org/10.1016/j.semcdb.2016.06.005.

Sripong, K., Jitareerat, P., and Uthairatanakij, A. (2019). UV irradiation induces resistance against fruit rot disease and improves the quality of harvested mangosteen. Postharvest Biol. Technol. 149, 187-194. https://doi.org/10.1016/j.postharvbio.2018.12.001.

Suktawee, S., Shishido, M., Wang, S., Saito, T., Okawa, K., Ohara H., Nimitkeatkai, H., Ikeura, H., and Kondo, S. (2019). n-Propyl dihydrojasmonates influence ethylene signal transduction in infected apple fruit by Botrytis cinerea. Hortic. J. 88, 41-49. https:// doi.org/10.2503/hortj.UTD-001.

Sun, H., Song, N., Ma, L., Li, J., Ma, L., Wu, J., and Wu, J. (2016). Ethylene signalling is essential for the resistance of Nicotiana attenuata against Alternaria alternata and phytoalexin scopoletin biosynthesis. Plant Pathol. 66(2), 277-284. https://doi.org/10.1111/ppa.12568.

Wang, N., Guo, T., Wang, P., Sun, X., Shao, Y., Jia, X., Liang, B., Gong, X., and Ma, F. (2017). MhYTP1 and MhYTP2 from Apple confer tolerance to multiple abiotic stresses in Arabidopsis thaliana. Front. Plant Sci. 8,1367-1367. https://doi.org/10.3389/fpls.2017.01367.

Xu, W., Wang, T., Xu, S., Li, F., Deng, C., Wu, L., Wu, Y., and Bian, P. (2016). UV-C-Induced alleviation of transcriptional gene silencing through plant-plant communication: Key roles of jasmonic acid and salicylic acid pathways. Mutat. Res. 790, 56-67. https://doi. org/10.1016/j.mrfmmm.2016.04.003.

Xu, Y., Charles, M.T., Luo, Z., Mimee, B., Tong, Z., Roussel, D., Rolland, D., and Véronneau, P.Y. (2019). Preharvest UV-C treatment affected postharvest senescence and phytochemicals alternation of strawberry fruit with the possible involvement of abscisic acid 
regulation. Food Chem. 299, 125-138. https://doi.org/10.1016/j. foodchem.2019.125138.

Yang, J., Duan, G., Li, C., Liu, L., Han, G., Zhang, Y., and Wang, C. (2019). The crosstalks between jasmonic acid and other plant hormone signaling highlight the involvement of jasmonic acid as a core component in plant response to biotic and abiotic stresses. Front. Plant Sci. 10, 1349. https://doi.org/10.3389/fpls.2019.01349.

Received: Aug. 5, 2020

Accepted: Nov. 10, 2020

Address of authors:

Orathai Phonyiam, Hiroyuki Tomiyama, Peter Opio, Takanori Saito, Katsuya Ohkawa, Hitoshi Ohara and Satoru Kondo*

Graduate School of Horticulture, Chiba University, Matsudo, Chiba 271-8510, Japan

* Corresponding author; E-mail: s-kondo@faculty.chiba-u.jp 